\title{
AL-AWQAF
}

Jurnal Wakaf dan Ekonomi Islam

Vol. 13, No. 2, Tahun 2020

\section{Pemberdayaan Ekonomi Masyarakat Desa Melalui Manajemen Aset Wakaf Berbasis Skim Mudhorobah dan Ijarah}

\author{
Mohamad Ainun Najib ${ }^{1}$, Najmudin ${ }^{2}$ \\ 1,2, Universitas Sultan Ageng Tirtayasa, Serang, ainun.najib@untirta.ac.id
}

\begin{abstract}
This study aims to describe the portrait of waqf system and the model of waqf asset empowerment at the village level of Banten Province in the context of community economic empowerment. The object of this research study is nazir waqf at the village level of Banten province. The method used is descriptive qualitative method. Data collection methods were carried out by interviews and field surveys. Data analysis was performed using the Miles and Huberman analysis model, in which data analysis from surveys and interviews was carried out in three stages, there are data reduction, data supply and conclusion drawing. The results of this study indicate two things. Firts, the contributors (waqif) donate their assets to the nazir on the basis of religious spirit and the expectation of the reward that continues to flow for waqif. Most of the waqf asset managers at the village level of Banten province are the prosperity council of the local village mosques (DKM), not the professional nazir that has been established by the Indonesian Waqf Board. Most of the waqf lands managed by DKM do not have waqf certification. The reporting of waqf assets is carried out in several ways, including through announcements delivered before the prayer takes place. Second, the model of waqf asset management in the context of economic empowerment of the village community is carried out with two schemes; mudharabah and ijarah. The mudharabah scheme is carried out with the nazir mechanism of giving up waqf assets in the form of agricultural land and plantations to be managed by the mudharib, after harvest, the results are divided in two between the nazir and the manager. The ijarah scheme is carried out by leasing a rented house or shop built on a waqf land to the tenant, the annual income reaches ten to fifteen million, in addition, nazir also rents out rice fields to farmers with affordable rental fees. All proceeds obtained from the two schemes are intended for mosque cash savings, mosque operational costs and costs for social-religious and community activities.
\end{abstract}

Keywords: Ijarah, Mudharabah, Nazir, Empowerment, Waqf.

\begin{abstract}
Abstrak: Penelitian ini bertujuan untuk menggambarkan potret sistem perwakafan dan model pemberdayaan aset wakaf di tingkat desa Provinsi Banten dalam rangka pemberdayaan ekonomi masyarakat. Objek kajian penelitian ini adalah nazir wakaf di tingkat desa provinsi Banten. Metode yang digunakan adalah metode kualitatif deskriptif. Metode pengumpulan data dilakukan dengan wawancara dan survei lapangan. Analisis data dilakukan dengan model analisis Miles dan Huberman, di mana analisis data hasil survei dan wawancara dilakukan dalam tiga tahap, yaitu, reduksi data, suplai data, dan penarikan kesimpulan. Hasil penelitian ini menunjukan dua hal. Pertama, para wakif mewakafkan hartanya kepada nazir atas dasar spirit keagamaan dan pengharapan akan pahala jariah yang terus mengalir untuk wakif. Pengelola aset wakaf di tingkat desa provinsi Banten sebagian besar adalah Dewan Kemakmuran Masjid desa setempat, bukan nazir profesional yang telah dibentuk Badan Wakaf Indonesia. Sebagian besar lahan wakaf
\end{abstract}


yang dikelola DKM belum memiliki sertifikasi wakaf. Pelaporan harta aset wakaf dilakukan dengan beberapa cara, di antaranya melalui pengumuman yang disampaikan sebelum pelaksanaan shalat berlangsung. Kedua, model pengelolaan aset wakaf dalam rangka pemberdayaan ekonomi masyarakat desa dilakukan dengan dua skim; mudharabah dan tijarah. Skim mudharabah dilakukan dengan mekanisme nazir menyerahterimakan aset wakaf berupa lahan pertanian dan perkebunan untuk dikelola oleh mudharib, setelah panen, hasil dibagi dua antara nazir dan pengelola. Skim ijarah dilakukan dengan cara mengontrakkan rumah kontrakan atau ruko yang dibangun di atas lahan wakaf pada penyewa. Penghasilan pertahunnya mencapai kisaran sepuluh sampai lima belas juta rupiah. Di samping itu, nazir juga menyewakan sawah kepada para petani dengan biaya sewa yang terjangkau. Seluruh hasil yang diperoleh dari dua skim tersebut diperuntukan untuk simpanan kas masjid, biaya operasional masjid, dan biaya kegiatan sosial keagamaan dan kemasyarakatan.

Kata Kunci: Ijarah, Mudharabah, Nazir, Pemberdayaan, Wakaf.

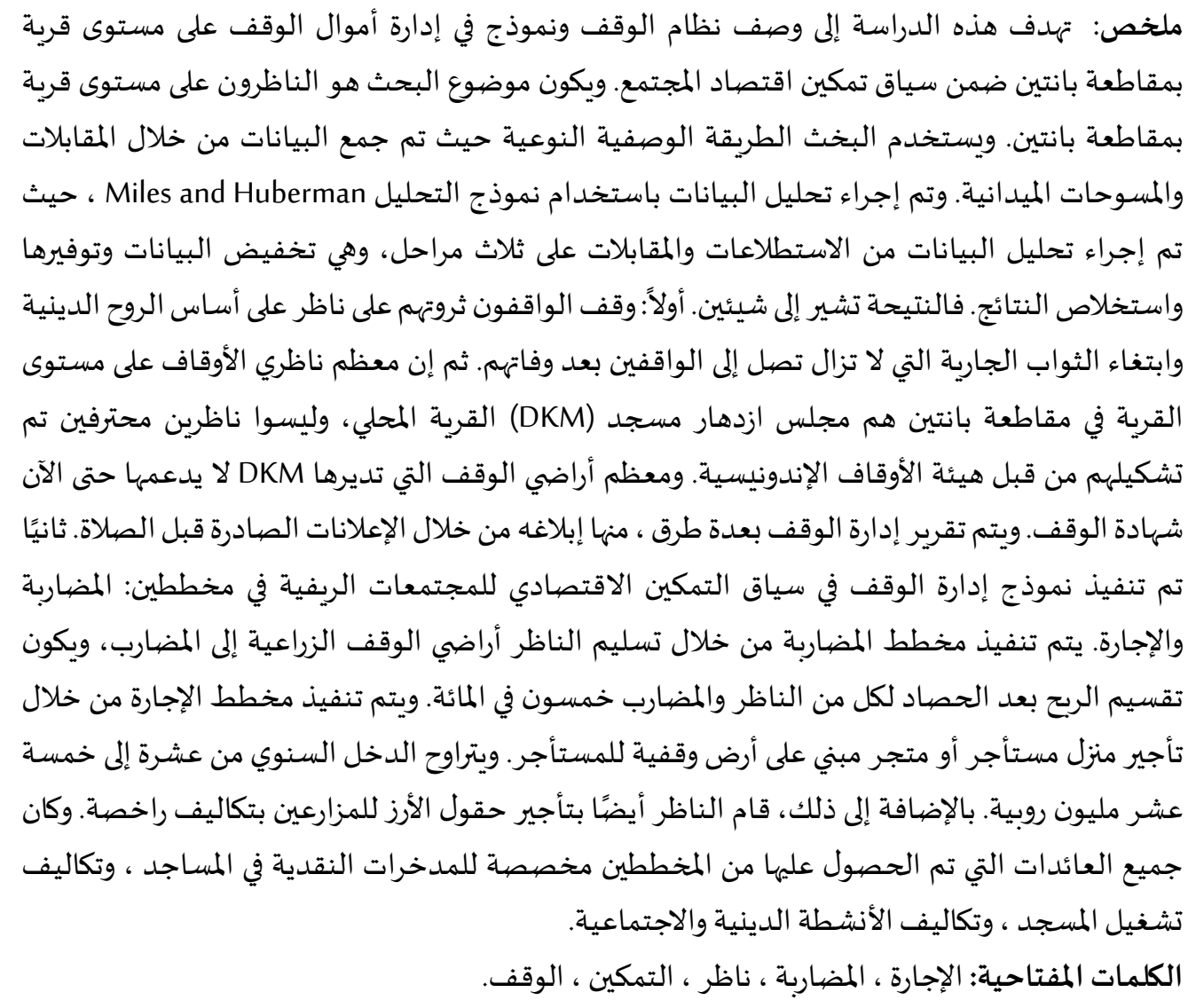

\section{Pendahuluan}

Permasalahan kehidupan yang dihadapi masyarakat di Indonesia sangat banyak, terutama permasalahan pada sektor ekonomi yang meliputi penghasilan yang minim, daya saing yang rendah dalam pengelolaan sumber-sumber ekonomi nasional, tingkat pengangguran tinggi, keterbatasan kemampuan dalam mengelola kegiatan bisnis, keterbatasan kemampuan dalam menyandingkan sumber-sumber informasi dan teknologi industri, ketidakmerataan kemakmuran dan kesejahteraan hidup yang tinggi, dan lain sebagainya.

Apalagi ditambah adanya pandemi global covid 19 yang mengakibatkan pertumbuhan ekonomi menurun dalam skala nasional. Termasuk untuk wilayah Banten sebagimana disampaikan Kepala BI Perwakilan Provinsi Banten Erwin Soeriadimadja mengatakan "Untuk keseluruhan 
tahun 2020, perekonomian Provinsi Banten diperkirakan akan lebih rendah dibandingkan tahun 2019 disebabkan oleh adanya pandemi Covid-19 yang menahan pertumbuhan konsumsi rumah tangga, investasi, baik swasta maupun pemerintah, dan kinerja ekspor baik antar daerah maupun luar negeri. Perlambatan pertumbuhan ekonomi Provinsi Banten tersebut akan berdampak pada penurunan tekanan inflasi pada tahun 2020. (bantenprov.go.id, n.d.) diakses tanggal (23 september 2020 pukul 17.00) Padahal sangat jelas pada alinea keempat dalam pembukaan UUD Negara Republik Indonesia tahun 1945 tertuang tujuan daripada Negara Indonesia yang diantaranya adalah memajukan kesejahteraan umum. Tuntutan untuk mewujudkan kesejahteraan umum sebagaimana yang tertuang di dalam konstitusi diantaranya adalah penguatan dibidang ekonomi yang bersendikan nilai-nilai bangsa Indonesia yang dirumuskan dalam Pancasila sebagai dasar Negara Indonesia. Ekonomi yang kuat akan menunjang kesejahteraan sosial dan masyarakat pun dapat merasakan manfaat dari kekuatan ekonomi itu secara merata. (Handayani, 2011)

Salah satu Instrumen yang bisa membantu memulihkan perekonomian masyarakat adalah wakaf. Karena kalau pengelolaan wakaf diberdayakan dengan baik maka wakaf akan menjadi sangat potensial dalam membantu menghadapi berbagai krisis khususnya krisis ekonomi yang dihadapi masyarakat kurang mampu. Apalagi kalau pemanfaatannya berubah dari konsumtif menjadi produktif. Karena sejatinya wakaf dalam aturan Islam mengeluarkan bagian sumber daya produktif dalam masyarakat dari ranah manfaat individu bersamaan dengan ranah kebijakan pemerintah untuk membantu kegiatan sosial masyarakat, membantu umat dan perbaikan bagi generasi selanjutnya. (Qohaf, 2006) padahal wakaf bisa dijadikan instrumen pemberdayaan masyarakat sebagaimana ketentuan menurut undang-undang wakaf, wakaf bukan sekedar untuk kebutuhan itu, melainkan untuk pembangunan ekonomi dan pengembangan skill masyarakat, salah satunya dengan wakaf produktif, diharapkan institusi keagamaan dapat menjadi sektor-sektor strategis dalam pembangunan masyarakat. Oleh karenanya, pengembangan dan peningkatan kapasitas para nazir pun harus dilakukan. Para pengelola wakaf sudah seharusnya secara perlahan merubah orientasi pengurusan wakaf menjadi profesional, walau tidak melulu harus produktif. (Fauzia et al., 2018) Apalagi di tambah dukungan politik dari pemerintah dengan mengeluarkan peraturan undang-undang terkait wakaf produktif. (Kurniawan, 2013)

Selain problematika wakaf seperti kurangnya pemahaman dan kepedulian umat Islam terhadap wakaf khususnya ditingkat pedesaan. (Abdullah, 2013) Peruntukan wakaf hanya untuk memenuhi kebutuhan infrastruktur keagamaan, seperti masjid dan pemakaman. Oleh karena itu, kita perlu menciptakan usaha-usaha atau lapangan pekerjaan sebagai salah satu alternatif untuk mengurangi tingkat kemiskinan dan pengangguran, yang salah satunya dengan memberdayakan masyarakat dengan wakaf produktif dengan skim Ijarah dan mudhorobah. Sehingga wakaf bisa dikembangkan sesuai dengan prinsip dan tujuan disyariatkannya wakaf.

Berdasarkan urian di atas maka penelitian ini bertujuan untuk (1) menggambarkan potret sistem pengelolaan aset wakaf di tingkat desa Provinsi Banten dan (2) menggambarkan model pengelolaan aset wakaf dengan skema mudharabah dan ijarah di tingkat desa dalam rangka pemberdayaan ekonomi masyarakat desa. 


\section{Landasan Teoritis}

Konsep Wakaf

Istilah wakaf dalam bahasa arab artinya menahan atau mencegah. Sedangkan dalam istilah Ulama Islam berbeda pendapat dalam memberikan definisi kata wakaf. Hanafiyah mengartikan wakaf sebagai menahan materi benda (al-'ain) milik Wakif dan menyedekahkan atau mewakafkan manfaatnya kepada siapapun yang diinginkan untuk tujuan kebajikan (Ibnu alHumam: 6/203). Imam Abu Hanifah memandang akad wakaf tidak mengikat dalam artian bahwa orang yang berwakaf boleh saja mencabut wakafnya kembali dan boleh diperjual belikan oleh pemilik semula (Megawati, 2014).

Menurut Malikiyah, wakaf adalah menjadikan manfaat suatu harta yang dimiliki (walaupun pemilikannya dengan cara sewa) untuk diberikan kepada orang yang berhak dengan satu akad dalam jangka waktu tertentu sesuai dengan keinginan Wakif (al-Dasuqi: 2/187). Definisi wakaf tersebut hanya menentukan pemberian wakaf kepada orang atau tempat yang berhak saja. Menurut Imam Al-Mināwi mendefinisikan wakaf sebagai supaya upaya menahan harta benda yang dimiliki dan menyalurkan manfaatnya dengan tetap menjaga pokok barang dan keabadiannya yang berasal dari para dermawan atau pihak umum, selain harta yang dihasilkan dari perbuatan maksiat semata-mata karena ingin mendekatkan diri kepada Allah (Suryani \& Isra, 2016). Definisi yang diberikan al-Minawi senada dengan pandangan Imam Syafii, pendiri Madzhab Syafii yang dianutnya. Syafii memandang bahwa harta yang telah diwakafkan sudah berpindah dari kepemilikan wakif, menjadi kepemilikan umum.

Perbedaan pandangan para ahli madzhab di atas dijembatani oleh hukum positif yang berlaku di Indonesia yakni Undang-Undang No. 41 tahun 2004 tentang Wakaf. Dalam Bab 1 pasal 1 disebutkan bahwa wakaf adalah perbuatan hukum wakif untuk memisahkan dan/atau menyerahkan sebagian harta benda miliknya untuk dimanfaatkan selama- lamanya atau untuk jangka waktu tertentu sesuai dengan kepentingannya guna keperluan ibadah dan/atau kesejahteraan umum menurut syariah. Undang-undang No 41 Tahun 2004 lebih jauh menjelaskan bahwa wakaf dilaksanakan dengan memenuhi unsur wakaf berikut, yaitu, Wakif (orang yang mewakafkan hartanya), Nadhir (orang yang mengelola harta wakaf), harta benda wakaf, ikrar wakaf, peruntukan harta benda wakaf, dan jangka waktu wakaf. Undang-undang tersebut juga menjelaskan jenis harta benda wakaf, yakni harta benda yang memiliki daya tahan lama dan/atau manfaat jangka panjang serta mempunyai nilai ekonomi menurut syariah yang diwakafkan oleh wakif. Harta benda wakaf terdiri dari benda tidak bergerak dan benda bergerak. Benda tidak bergerak tersebut meliputi hak atas tanah, bangunan atau bagian bangunan yang berdiri di atas tanah, tanaman, hak milik atas satuan rumah dan benda tidak bergerak lain sesuai dengan ketentuan syariah dan peraturan perundang-undangan yang berlaku. Sedangkan benda bergerak meliputi uang, logam mulia, surat berharga, kendaraan, hak atas kekayaan intelektual, hak sewa dan benda bergerak lain yang sesuai dengan syariah dan peraturan perundang-undangan yang berlaku. (UU Wakaf, 2004).

Sedangkan yang dimaksud wakaf produktif adalah harta benda atau pokok tetap yang diwakafkan untuk dipergunakan dalam kegiatan produktif dan hasilnya disalurkan sesuai dengan tujuan wakaf, seperti wakaf tanah untuk dipergunakan untuk bercocok tanam, mata air untuk dijual airnya (Mundzir Qahaf, 2008). Atau juga bisa dipahami transformasi (pengalihan) 
dari pengelolaan alami atau konvensional menjadi pengelolaan wakaf yang professional untuk meningkat atau menambah manfaat wakaf itu sendiri (Mubarok, 2008). Jadi yang di maksud wakaf produktif dilihat dari obyek tujuannya, yaitu untuk memaksimalkan fungsi wakaf dan meningkatkan peranannya dalam meningkatkan ekonomi masyarakat sebagaimana tujuan utama dari wakaf tersebut.

\section{Wakaf dengan Skema Mudharabah dan Ijarah}

Secara etimologi mudharabah berasal dari kata dharbu satu makna dengan sairu, berarti memukul atau berjalan, artinya : berjalan dengan tujuan mencari rizki Allah Swt. Istilah Mudharabah (Masyarakat Irak) sepadan dengan Istilah Qiradh (Masyarakat Hijaz). (Salus, 2002). Menurut terminologi adalah Menyerahkan harta kepada pihak lain untuk dikelola dengan mendapat keuntungan bersama. (Najib, 2017) dalam (Muhammad bin Yusuf AlAbadri). Secara teknis, mudharabah adalah sebuah akad kerja sama antarpihak, yaitu pihak pertama (shahibul mal) menyediakan seluruh (100\%) modal; sedangkan pihak lainnya menjadi pengelola. (Antonio, 1999)

Menurut UU No. 21 Tahun 2008 tentang Perbankan Syari'ah, mudharabah akad kerja sama suatu usaha antara pihak pertama (malik/shahibul mal, atau bank syari'ah) yang menyediakan seluruh modal dan pihak kedua ('amil/mudharib, atau nasabah) yang bertindak selaku pengelola dana dengan membagi keuntungan usaha sesuai dengan dengan kesepakatan yang dituangkan dalam akad, sedangkan kerugian ditanggung sepenuhnya oleh Bank Syariah kecuali jika pihak kedua melakukan kesalahan yang disengaja, lalai atau menyalahi perjanjian.

Ijarah disebut juga lease contract dan hire contarckt. Dari aspek bahasa, istilah "Al Ijarah" berasal dari kata $A l$-Ajru artinya al-Jaza (pahala) Al-Iwadu (ganti). Atau juga bisa diartikan upah. Sedangkan menurut Istilah adalah suatu jenis akad untuk mengambil manfaat dengan jalan penggantian yaitu uang. (Al-Jurjani : Al-Ta'rifat). Hanafiah mengartikan ijarah dengan akad untuk memperoleh manfaat sebagai penggantian dari barang yang disewakan; barang itu jelas; dan manfaat kesesuaian baik syara' maupun akal. Sedangkan Menurut hanabilah akad yang memperoleh manfaat yang dibolehkan, waktunya ditentukan, barangnya diketahui ; manfaat diperoleh secara berangsur-angsur dan memiliki nilai. Ijarah menurut Fatwa DSN MUI No. 09/DSN MUI/IV/2000: akad pemindahan hak guna pakai (manfaat) atas suatu barang atau jasa dalam waktu tertentu melalui pembayaran sewa atau upah, tanpa diikuti pemindahan kepemilikan barang itu sendiri.

Terkait model skema wakaf dengan skim mudhorobah dan ijarah, Monzer Kahf menyebutkan beberap model pembiayaan wakaf yang dipraktekkan oleh ulama terdahulu, dan menyebutnya sebagai model pembiayaan tradisional, yaitu: penambahan wakaf lama dengan wakaf baru, alIqtirädh (peminjaman), Ibdàl dan istibdāl (penukaran), Hukr (Sewa Berjangka Panjang dengan Lump Sum Pembayar di Muka yang Besar), alljäratain (penyewaan dengan dua kali pembayaran) (Qohaf, 2006).

Model pembiayaan wakaf tanah apabila ditarik garis besarnya tidak terlepas dari tiga prinsip pembiayaan Islam, yaitu: prinsip bagi hasil/ resiko (musyārakah), prinsip jual beli (ba’i) dan prinsip sewa (ijārah). Untuk menjaga harta wakaf agar tetap utuh, dalam proses penyewaaan 
obyek wakaf harus memenuh beberapa unsur di antaranya ; a. Menjaga wakaf dengan memperuntukan untuk yang lebih bermanfaat. Bagi seorang nazdhir wakaf hendaknya menjaga kemanfaatan wakaf, yang sesuai dengan prinsip syari'ah. Termasuk ketika menyewakan obyek wakaf. Jika penyewa wakaf lebih dari satu hendaknya lebih memperhatikan yang lebih dipercaya dan dikenal memiliki reputasi yang baik khususnya terkait pembayaran sewa. Dalam penerapan model pembiayaan ijārah terhadap tanah wakaf adalah nazhir memberikan izin kepada financer (penyedia dana) untuk mendirikan sebuah gedung diatas tanah wakaf. Kemudian nazhir menyewakan gedung tersebut untuk jangka waktu yang sama dimana pada periode tersebut dimiliki oleh penyedia dana, dan digunakan untuk tujuan wakaf. Gedung tersebut bisa berupa rumah sakit, sekolah, perkantoran, pusat bisnis, atau apartemen. Nazhir menjalankan manajemen dan membayar sewa secara periodik kepada penyedia dana sesuai dengan biaya sewa yang telah ditetapkan sehingga menutup modal pokok dan keuntungan yang dikehendaki oleh penyedia dana. Apabila masa pembayaran sewa telah selesai maka kepemilikan bangunan tersebut berpindah milik dari penyedia dana kepada nazhir wakaf tanah tersebut.

\section{Pemberdayaan Ekonomi}

Pemberdayaan menurut pandangan (Suharto, 2014) menunjuk pada kemampuan orang, khususnya kelompok rentan dan lemah sehingga mereka memiliki kekuatan atau kemampuan dalam (a) memenuhi kebutuhan dasarnya, sehingga mereka memiliki kebebasan (freedom), dalam arti bukan saja bebas mengemukakan pendapat, melainkan bebas dari kelaparan, bebas dari kebodohan, dan bebas dari kesakitan. (b) menjangkau sumber-sumber produktif yang memungkinkan mereka dapat meningkatkan pendapatannya dan memperoleh barang-barang dan jasa-jasa yang mereka perlukan dan (c) berpartisipasi dalam proses pembangunan dan keputusan-keputusan yang mempengaruhi mereka. Menurut Ife seperti yang dikutip (Suharto, 2014), pemberdayaan memuat dua pengertian kunci, yakni kekuasaan dan kelompok lemah. Kekuasaan di sini diartikan bukan hanya menyangkut kekuasaan politik dalam arti sempit, melainkan kekuasaan atau penguasaan klien atas :

1. Pilihan-pilihan personal dan kesempatan-kesempatan hidup: kemampuan dalam mengambil keputusan-keputusan mengenai gaya hidup, tempat tinggal, pekerjaan.

2. Pendefinisian kebutuhan: kemampuan menentukan kebutuhan selaras dengan aspirasi dan keinginannya.

3. Ide atau gagasan: kemampuan mengekspresikan dan menyumbangkan gagasan dalam suatu forum atau diskusi secara bebas tanpa tekanan.

4. Lembaga-lembaga: kemampuan menjangkau, menggunakan dan mempengaruhi pranata-pranata masyarakat, seperti lembaga kesejahteraan sosial, pendidikan dan kesehatan.

5. Sumber-sumber: kemampuan memobilisasi sumber-sumber formal, informal dan kemasyarakatan.

6. Aktivitas ekonomi: kemampuan memanfaatkan dan mengelola mekanisme produksi, distribusi, dan pertukaran barang serta jasa.

7. Reproduksi: kemampuan dalam kaitannya dengan proses kelahiran, perawatan anak, pendidikan dan sosialisasi. 


\section{Metode Penelitian}

Sesuai dengan pokok permasalahan, penelitian ini menggunakan metode kualitatif dengan pendekatan Saintifik Yuridis Normatif, pendekatan yang dilakukan berdasarkan bahan hukum utama dengan cara menelaah teori-teori, konsep-konsep, asas-asas hukum serta peraturan perundang-undangan dan dokumen lainya, yakni mempelajari masalah-masalah dalam masyarakat, tata cara yang berlaku dalam masyarakat, serta situasi-situasi tertentu termasuk tentang hubungan kegiatan-kegiatan, sikap-sikap, pandangan-pandangan, serta proses-proses yang sedang berlangsung dan pengaruh-pengaruh dari suatu fenomena. Dan biasanya hasil dari penelitian kasus ini biasanya generalisasi dari pola-pola kasus yang tipikal dari invidu, kelompok, Lembaga dan sebagainya. (Nazir \& Sikumbang, 2014). Beberapa pendekatan yang dilakukan diantaranya: 1).Pendekatan perundang-undangan (statute approach), 2). Pendekatan Konsep (conceptual approach), 3). Pendekatan Penelitian Sosiologis atau empiris. Cara kerja dari metode yuridis sosiologis dalam penelitian ini, yaitu dari hasil pengumpulan dan penemuan data serta informasi melalui studi kepustakaan terhadap asumsi atau anggapan dasar yang dipergunakan dalam menjawab permasalahan pada penelitian ini, kemudian dilakukan pengujian secara induktif-verifikatif pada fakta mutakhir yang terdapat di dalam masyarakat. (Bungin, 2013)

Data yang dikumpulkan terdiri dari data primer dan data sekunder. Data primer adalah data yang diperoleh atau dikumpulkan langsung dari informan ataupun responden di lapangan yang merupakan Nazdir (pengelola wakaf) sekaligus pengurus Dewan Kemakmuran Masjid (DKM), dan dari masyarakat di beberapa desa di Provinsi Banten. Pada penelitian ini jawaban data primer diperoleh dari hasil wawancara Bapak Robin ketua DKM Nurul Iman Sukasari Pandeglang, Bapak Obi dari perwakilan DKM Desa Jiput kabupaten Pandeglang, Bapak Arsa pengurus Ziswaf Desa Gunung Cupu Kecamatan Cimanuk, Kabupaten Pandeglang, Tokoh masyarakat di Desa Jombang Wetan baik dari pengurus DKM Masjid agung Nurul Ikhlas atau tokoh masyarakat lainnya. Kemudian perwakilan tokoh desa Sindangsari kabupaten Serang seperti Bapak Iing dan lainnya. Dalam melakukan wawancara, tim peneliti bertemu langsung dengan memberikan pertanyaan-pertanyaan langsung dan terbuka yang berkaitan dengan sejarah dan proses awal pendirian Lembaga wakaf, manajemen atau pengelolaan wakaf baik dengan skim mudhorobah atau skim ijarah dan peruntukan obyek wakaf. Selain melalui wawancara, dilakukan pengamatan terkait pengelolaan dan obyek wakaf di tempat penelitian tersebut.

Data sekunder merupakan informasi yang diperoleh dari berbagai data, dokumen, buku, jurnal atau referensi lain yang menunjang dan sesuai dengan tujuan penelitian. Data ini diperoleh dari melalui studi kepustakaan yang berkaitan dengan wakaf dan pemberdayaan masyarakat desa. Tujuannya untuk mensinkronkan antara teori dengan data di lapangan. Dan juga dari sumber lain yang berkaitan dengan profil pemerintah daerah mulai dari pendidikan, kondisi keagamaan, kondisi ekonomi dan sosial.

Metode yang akan peneliti gunakan untuk menganalisis data yang terkumpul melalui metode pengumpulan di atas adalah metode analisis data model Miles dan Hubermen. Dalam model analisis Miles dan Huberman ada tiga tahap kegiatan analisis data kualitatif, yaitu: Reduksi data (data reduction), mereduksi data berarti merangkum, memilih hal-hal pokok, memfokuskan pada hal-hal yang penting, dicari tema dan polanya, dan membuang yang tidak perlu. Setelah data direduksi, maka langkah selanjutnya adalah penyajian data (data display). Dalam penelitian data kuantitatif penyajian data ini dapat dilakukan dalam bentuk table, grafik, phie card, pictogram, dan sejenisnya, sedangkan dalam penelitian kualitatif, penyajian data bisa dilakukan dalam bentuk uraian singkat, bagan, hubungan antar kategori, Flowchart dan sejenisnya. Langkah ketiga dalam analisis data Miles dan Huberman adalah penarikan dan verifikasi 
kesimpulan. Kesimpulan awal yang dikemukakan masih bersifat sementara, dan akan berubah bila tidak ditemukan bukti-bukti yang kuat dan mendukung pada tahap pengumpulan berikutnya. Tetapi apabila kesimpulan yang dikemukakan pada tahap awal didukung buktibukti yang valid dan konsisten saat peneliti kembali ke lapangan untuk mengumpulkan data dari berbagai sumber, maka kesimpulan yang dikemukakan merupakan kesimpulan yang kredibel ( dipertanggung jawabkan). (Emzir, 2012)

\section{Hasil dan Pembahasan}

\section{Potret Sistem Perwakafan di Tingkat Desa di Provinsi Banten}

\section{Desa Sukasari, Pandeglang}

Secara umum pembangunan tanah-tanah di Desa Sukasari dilakukan dengan dua model pembiayaan. Sebagian ada bangunan yang dibiayai oleh pemerintah untuk kepentingan masyarakat, diantaranya pembangunan Gedung SDN Sukasari dan SMPN 1 Kaduhejo, Gedung Paud Rokoy, pembangunan Puskesmas Kaduhejo, termasuk juga pembangunan kantor urusan Agama di Kecamatan Kaduhejo. Dan juga bangunan yang dibiayai dengan dana wakaf di antaranya pembangunan masjid Nurul Iman, Lembaga Pendidikan seperti madrasah dan juga fasilitas jalan menuju pemakaman (Wawancara dengan Bapak Robin ketua DKM Nurul Iman, 09 Maret 2021)

Pengelolaan wakaf di desa Sukasari dikelola oleh Dewan Kemakmuran Masjid (DKM) Nurul Iman. Di struktur DKM ada beberapa divisi, di antaranya adalah divisi yang mengelola wakaf. Lembaga inilah yang menjadi Nazir wakaf yang berfokus pada pengelolaan wakaf produktif. Pengelolaan wakaf baik yang bersifat umum di Desa Sukasari tepatnya dikampung Caringin Kurung atau wakaf produktif dimulai sejak 10 tahun yang lalu. Secara umum jenis wakaf yang dikelola ialah wakaf umum dan wakaf produktif. Wakaf umum diperuntukan langsung untuk pembangunan sarana Ibadah. Sedangkan untuk wakaf produktif terdiri dari sawah yang di wakafkan oleh masyarakat setempat dan wakaf uang dari orang-orang mampu di sekitar Desa Sukasari.

Sistem pengelolaan wakaf produktif yang dikelola oleh pihak DKM masjid di desa Sukasari menggunakan skim bagi hasil atau yang dikenal dengan skim mudharabah. Praktek pelaksanaanya, DKM Nurul Iman selaku Nazir pengelola sawah melakukan kerjasama dengan masyarakat Desa Sukasari yang ingin mengelola sawah. Semua hal yang terkait dengan modal untuk bibit dan pupuk dibiayai dari dana wakaf. Kemudian hasil panen biasanya satu tahun 2 kali, hasil pertanian dijual kepada pihak lain. Setiap panen pendapatan sekali panen mencapai Rp. 1.200.000. Hasil penjualan dibagi menjadi dua, 50\% untuk pengelola sawah dan 50\% diperuntukan untuk kas masjid. Setelah mendapatkan hasil berupa uang, biasanya pihak DKM mendistribusikan dana tersebut untuk keperluan perbaikan masjid, pembayaran listrik, air, dan lain-lain, yang berguna untuk kepentingan umum. Selain skim mudhorobah, pengelolaan lahan produktif dilakukan dengan skim ijarah. Praktek skim ini, DKM Nurul Iman selaku Nazir menyewakan tanah atau sawah kepada masyarakat untuk dikelola. Pengelola mendapatkan upah dari pihak DKM sesuai kesepakan dan jumlah harinya. Nanti hasil panennya di jual ke pihak lain dan keuntungannya masuk ke saldo masjid untuk keperluan masjid. (Wawancana dengan Bapak Robin ketua DKM Nurul Iman, 09 Maret 2021) 
Sejauh pengamatan penulis, walaupun pengelolaan wakaf produktif sudah baik tapi belum maksimal, karena pengembangan dari hasil keuntungan yang didapat dari skim mudhorbah dan ijarah, peruntukan hasil wakaf masih terbatas untuk kepentingan masjid, dan belum dikembangankan lagi untuk pengembangan usaha bisnis atau pembelian tanah pertanian.

Terkait pengawasan pengelolaan wakaf tersebut biasanya dilakukan setiap bulan, dengan mengontrol jalannya wakaf produktif tersebut, apakah ada kendala atau tidak, dan bermusyawarah ketika terjadi masalah dalam pengelolaannya. Selain itu, pengelola wakaf juga melakukan sosialisasi kepada masyarakat terkait dengan perkembangan wakaf produktif di kampung tersebut, biasanya dilakukan tiap hari jumat, dimana pihak DKM akan menginformasikan jumlah wakaf maupun pengelolaannya kepada masyarakat. (Wawancana dengan Bapak Robin ketua DKM Nurul Iman, 09 Maret 2021)

Dengan adanya wakaf produktif, membuat masyarakat menjadi terbantu dalam bidang perekonomian dan kebutuhan masjid menjadi tercukupi. Dan masyarakat juga menjadi lebih nyaman ketika berada di masjid, karena dikelola dengan baik, khususnya dalam hal keuangan yang dibantu dengan wakaf produktif. Sampai saat ini, pemerintah tidak ikut serta dalam wakaf produktif tersebut, dimana wakaf produktif didapat dari masyarakat dan dikelola oleh pihak DKM masjid.

\section{Desa Jiput, Kabupaten Pandeglang}

Pengelolaan wakaf ini dibangun hasil inisiatif pribadi Bapak Obi dan masyarakat di Desa Jiput sebagai pengembangan Lembaga wakaf yang sudah ada seperti Badan Wakaf yang dikelola pemerintah. Obyek wakaf kebanyakan tanah yang dijadikan tempat pemakaman, sekolah, masjid , mushola, sawah, dan kebun,(Wawancara dengan Bapak Obi ketua Pengelola Ziswaf)

Obyek wakaf diberikan dari para orang-orang mampu di Desa Jiput karena kesadaran untuk berbagi dengan orang lain, keinginan memisahkan sebagian hartanya untuk berbagi dan diberikan kepada masyarakat khususnya yang tidak mampu. Ada kesadaran yang baik dari masyarakat ketika memiliki penghasilan sebagian assetnya diperuntukan untuk wakaf. Contoh yang memiliki uang 10 juta maka 1 jutanya diperuntukan untuk wakaf, yang memiliki 10 bidang sawah 1 bidangnya diwakafkan ke masjid. Untuk menghindari penyelewangan asset wakaf dan tuntutan ahli waris, pihak DKM mewajibkan setiap asset yang diwakafkan akta ikrar. Agar wakaf itu wajib tercatat di sana dan tertera namanya.

Pengelolaan wakaf di Desa Jiput termasuk zakat, infaq sedekah semuanya dikelola oleh DKM Masjid setempat. Pihak DKM memiliki bidang khusus yang menerima wakaf, zakat, infak dan sedekah dari masyarakat. Untuk pengelolaan wakaf selain untuk pembangunan masjid, mushola dan makam, ada juga pengelolaan wakaf produktif berupa sawah dan kebun. Pengelolaan wakaf produktif tersebut menggunakan skim Ijarah. Praktek pengelolaan dengan cara dikontrakkan sawah tersebut sebesar 1 juta pertahun. Sehingga pemasukan dari sewa sawah yang ada sekitar 3 hektar menghasilkan 10 sampai dengan 15 juta. Selain disewakan, sebagian sawah dan perkebunan di ditanami pepohonan seperti kelapa dan pisang. Dari hasil asset tanah yang disewakan dan hasil tanaman semuanya diperuntukan untuk kas Masjid. Kemudian dikelola oleh pihak DKM untuk pemberdayaan masyarakat, memperbaiki fasilitas 
masjid, perbaikan jalan menuju makam, kafalah marbot. (Wawancara dengan Bapak Obi ketua Pengelola Ziswaf)

\section{Desa Gunung Cupu, Kabupaten Pandeglang}

Kondisi obyektif pola manajemen wakaf di desa Gunung Cupu ini cukup baik dan masih aktif. Pemanfaatan wakaf ini dapat dirasakan oleh masyarakat di bidang keagamaan khusunya di Mushola. Desa Gunung Cupu terletak di Kec. Cimanuk, Kabupaten Pandeglang, Provinsi Banten. Sejarah wakaf ini dimulai dari Bapak Awing selaku warga desa Gunung Cupu yang mewakafkan sebidang sawah atas nama anaknya yang sudah meninggal yaitu Nur.

Pengelolaan harta wakaf tersebut, yaitu dengan cara memanfaatkan sawah. Sebidang sawah ditanami oleh Bapak. Arsa (orang yang di amanahkan untuk merawat sawah tsb). Setelah itu, ketika pada masa panen yaitu sekitar 3-4 bulan, hasil panen tersebut yang sudah di uang kan diberikan kepada Mushola. Kemudian, Uang yang diberikan kepada Mushola tersebut di masukkan ke Uang Kas Mushola, untuk berjaga-jaga apabila ingin merenovasi mushola, melakukan kegiatan-kegiatan agama, dan lainnya.

Pedistribusian hasil pengelolaan wakaf ini dibagi untuk Bapak Arsa sebagai pengelola dan Mushola sebagai pemilik tanah. Di desa Gunung Cupu tidak ini ada sosialisasi kepada masyarakat mengenai wakaf sawah tersebut. Skim yang digunaksn ialah akad mudharabah. Akad mudharabah adalah akad dimana Bapak Arsa sebagai pengelola, mengelola sawah Mushola yang nantinya hasil dari panen sawah tersebut dibagi untuk Bapak Arsa dan juga Mushola. Belum ada upaya dari pengelola dalam mengembangkan harta benda wakaf yang telah ada. Selain itu juga belum ada pengelolaan dan pengembangan aset wakaf dalam pemberdayaan ekonomi umat. Pengelolaan wakaf hanya berfokus pada hal hal yang bersifat keagamaan seperti pembangunan musholah dan acara acara keagamaan desa.

Manfaat yang dirasakan masyarakat ialah adanya peningkatan fasilitas masjid dan mudahnya akses untuk mengadakan acara acara keagamaan karena kas Mushola yang tercukupi. Belum ada peran dari pemerintah dalam membantu mengelola wakaf di desa ini. Pengambilan keputusan dalam pengelolaan wakaf produktif ini ialah hasil dari keputusan pengelola masjid dan pengelola wakaf.

Pelaporan dari pelaksaan wakaf dilakukan setiap selesai panen. Dan pengawasan yang dilakukan oleh Mushola kepada pengelola wakaf ini adalah kepercayaan yang kuat sehingga bisa dibilang tidak ada pengawasan yang tetap. Belum ada model kelembagaan wakaf yang dijadikan instrumen pemberdayaan ekonomi masyarakat Untuk itu, diperlukan perhatian kepada wakaf ini karena wakar ini mneimpan potensi yang cukup besar jika dikelola dengan baik.

\section{Desa Jombang Wetan, Kota Cilegon}

Pengelolaan wakaf di Desa Jombang Wetan di lakukan oleh DKM Masjid agung Nurul Ikhlas. Masjid ini terletak di pertengahan kota Cilegon yaitu berada di Jl. Perum Griya Cilegon, Jombang Wetan, Kec. Jombang, Kota Cilegon, Banten. Masjid ini didirikan pada tahun 1943 di atas tanah wakaf yang memiliki luas tanah 3,600 m2. Masjid ini begitu luas dan memiliki 
banyak fasilitas umum. Selain itu, masjid ini juga menyelenggarakan berbagai kegiatan keagamaan, serta adanya pemberdayaan zakat, infak, shodaqoh, dan wakaf.

Selain mengelola wakaf untuk pembangunan sarana tempat ibadah, DKM Masjid Agung juga mengelola wakaf produktif memanfaatkan tanah yang tersebar di beberapa daerah di sekitar Kota Cilegon. Dari beberapa tanah wakaf tersebut, ada yang sudah terdaftar dan memiliki sertifikat namun ada juga yang belum bersertifikat. Tanah wakaf ini didapatkan dari beberapa wakif yang memberikan kekuasaan penuh kepada DKM Masjid agung untuk mengelola tanah tersebut. Lalu, tanah wakaf itu dikelola dan dibangun oleh pengurus DKM Masjid agung berupa fasilitas sosial untuk kepentingan masyarakat sekitar, ada juga tanah wakaf yang diproduktifkan, dan ada juga tanah wakaf yang masih kosong (belum dikelola). (Wawancara dengan H.Ubed )

Untuk wakaf produktif, DKM Masjid agung mengelola salah satu tanah wakaf untuk diproduktifkan di bidang pertanian. Jadi, tanah wakaf tersebut dijadikan lahan untuk penanaman sayuran kangkung dengan menggunakan skim Mudhorobah/sistem bagi hasil. Pihak DKM memberikan kewenangan kepada masyarakat untuk mengelola. Penghasilannya 1 tahun menghasilkan Rp.1.000.000. Hasil keuntungannya diserahkan ke Masjid untuk kegiatan masyarakat dan santunan anak yatim.

Namun, dikarenakan hasilnya masih sangat minim, pengelolaan tersebut tidak bertahan lama karena dianggap kurang efektif.. Lalu pengurus DKM mengubah lahan pertanian tersebut menjadi sebuah kontrakan atau ruko yang diperuntukkan bagi para masyarakat yang ingin membangun suatu usaha. Sistem yang di pakai dengan skim ijarah, dengan cara menyewakan ruko dengan pembayaran upah diserahkan untuk kas Masjid. Kegiatan pengelolaan ini dianggap lebih menguntungkan daripada pengelolaan yang sebelumnya, karena dengan dibangunnya kontrakan skim ijarah ini mampu memberikan profit yang lebih besar yaitu sekitar Rp 10.000.000 dalam setahun. Dan hasil dari wakaf produktif ini kemudian digunakan untuk kegiatan sosial kemasyarakatan, santunan anak yatim, peringatan hari besar. kegiatan keagamaan, kebutuhan internal masjid, dan sisanya dimasukkan ke dalam kas masjid. (Wawancara dengan H.Ubed)

\section{Desa Sindangsari, Kabupaten Serang}

Salah satu desa yang mengadakan program wakaf di kabupaten serang adalah desa Sindangsari. Program pengelolaan wakaf di desa Sindangsari ini bermula program ini bermula ketika ada salah satu warga Sindangsari yang bermaksud mewakfkan tanahnya pada salah satu mesjid di desa Sindangsari yaitu masjid Uswatun Hasanah sebesar tiga kotak sawah. Waqif atau orang yang mewkafkan pertama di masjid ini bernama bapak awir. Beliau mewakafkan tiga bidang sawah yang berlokasi tak jauh dari masjid, dan pada saat itu belum terbentuk kepengurusan masjid maupun DKM, sehingga yang menerima wakaf pada saat itu adalah pencetus dari berdirinya masjid tersebut yaitu bapak kh. Abdul Madjid. Wakaf tersebut kemudian di kelola oleh pengurus atau marbot masjid tersebut. (Wawancara dengan Bapak ling ketua DKM), tanggal 6 maret 2021) 
Wakaf produktif, seperti: Sawah. Jumlah asset harta wakaf yang kini berada di masjid uswatun hasanah desa sindangsari berjumlah empat bidang sawah. Harta benda wakaf di masjid Uswatun Hasanah desa sindangsari berasal dari warga masjid itu sendiri, yang pertama yaitu bapak Awir dan yang kedua ibu Inoy.

Pengelolaan dengan cara mudhorobah bagi hasil antara pengelola dan pemilih lahan atas nama DKM. Kemudian hasilnya dibagi menjadi 2 dengan pembagian rata. Wakaf di Desa Sindangsari ini dikelola oleh DKM masjid, namun kemudian wakaf-wakaf tersebut di kelola kembali oleh warga sekitar masjid untuk ditanami padi dengan sistem bagi hasil.

Hasil dari wakaf produktif Desa Sindangsari dijual untuk kemudian hasil dari penjualan tersebut dipakai untuk keperluan masjid tersebut. Para DKM masjid yang berperan sebagai pengelaola masjid tidak turun tangan langsung ke masyarakat, hal itu dikarenakan kebiasaan dari masyarakat desa sindangsari sendiri yang bilamana ingin mengelola tanah wakaf bisa langsung bermusyawarah dengan DKM dan langsung menanaminya.

Sistem pengembangan aset wakaf yang dilakukan di Desa Sindangsari adalah sistem bagi hasil. Di Desa Sindangsari para pengelola wakafnya tidak melakukan upaya apapun untuk mengembangkan harta wakaf yang telah ada di masjid tersebut. Wakaf tersebut dikembangkan oleh DKM masjid dengan memberikan hak pengelolaan kepada masyarakat. Manfaat yang sudah dirasakan oleh masyarakat terkait dengan adanya pengelolaan wakaf produktif antara lain yaitu masyarakat merasa terbantu dengan pembiayaan yang harus dikeluarkan umtuk memenuhi kebutuhan pemeliharaan masjid. Dalam hal pengelolaan wakaf produktif ini tidak ada campur tangan dari pemerintah, semuanya dilakukan secara swadaya oleh para DKM masjid. Dalam hal pengambilan keputusan terkait wakaf produktif ini, semua keputusan diserahkan kepada ketua DKM masjid tentunya dengan jalan musyawarah bersama para pengurus masjid. Terkait pelaporan, sejauh ini belum ada pelaporan yang terstruktur dari $\mathrm{dkm}$. Semua bentuk laporan dilakukan secara langsung oleh pengelola kepada ketua DKM.Tak ada pengawasan khusus yang dilakukan oleh pengelola wakaf.

\section{Model Pemberdayaan wakaf dengan Skema Ijarah di Tingkat Desa di Provinsi Banten}

Berdasarkan hasil wawancara dengan para nazir di atas, dapat ditarik benang merah bahwa pengelolaan dan pengembangan aset wakaf sebagian besar dilakukan oleh Dewan Kemakmuran Masjid (DKM) atau pengurus Masjid setempat, yang notabene memegang kegiatan keagamaan secara umum di desa tersebut, bukan nazir profesional yang dibentuk oleh Badan Wakaf Nasional, Baik tingkat Kabupaten atau Kota maupun tingkat provinsi, para nazir juga belum mendapatkan edukasi manajemen perwakafan dari organisasi dan instansi terkait. Sehingga, penguasaan para nazir tentang administrasi dan manajerial wakaf masih terlihat minim, sebagai dampaknya hampir seluruh lahan wakaf di tingkat desa belum memiliki sertifikat wakaf. Aset wakaf dipegang nazir (DKM Masjid) atas dasar kepercayaan dan pengetahuan publik bahwa lahan tersebut adalah lahan wakaf, sebagai akibatnya tidak jarang terjadi konflik antara nazir dengan ahli warisnya di kemudian hari.

Kemudian juga terkait pengelolaan wakaf produktif masih terbatas memanfaatkan obyek wakaf yang ada, padahal bisa dikembangkan dari keuntungan yang masuk ke kas wakaf tidak semua 
harus digunakan untuk pembangunan fasilitas masjid dan sarana ibadah lainnya tetapi bisa dikembangkan untuk membeli asset sawah atau tanah baru yang bisa dipergunakan untuk ruko. Sehingga asset wakaf semakin banyak dan berkembang dan keuntungan yang didapatkan juga semakin banyak dan pemanfaatanya semakin maksimal untuk pemberdayaan masyarakat.

Meskipun demikian, nazir yang merangkap sebagai DKM Masjid tersebut secara riil sedikit banyak mampu memberdayakan aset wakaf melalui skim mudharabah dan ijarah. Berdasarkan potret perwakafan yang digambarkan oleh hasil wawancara di atas, maka model pemberdayaan aset wakaf secara sederhana dapat dilihat pada bagan berikut:

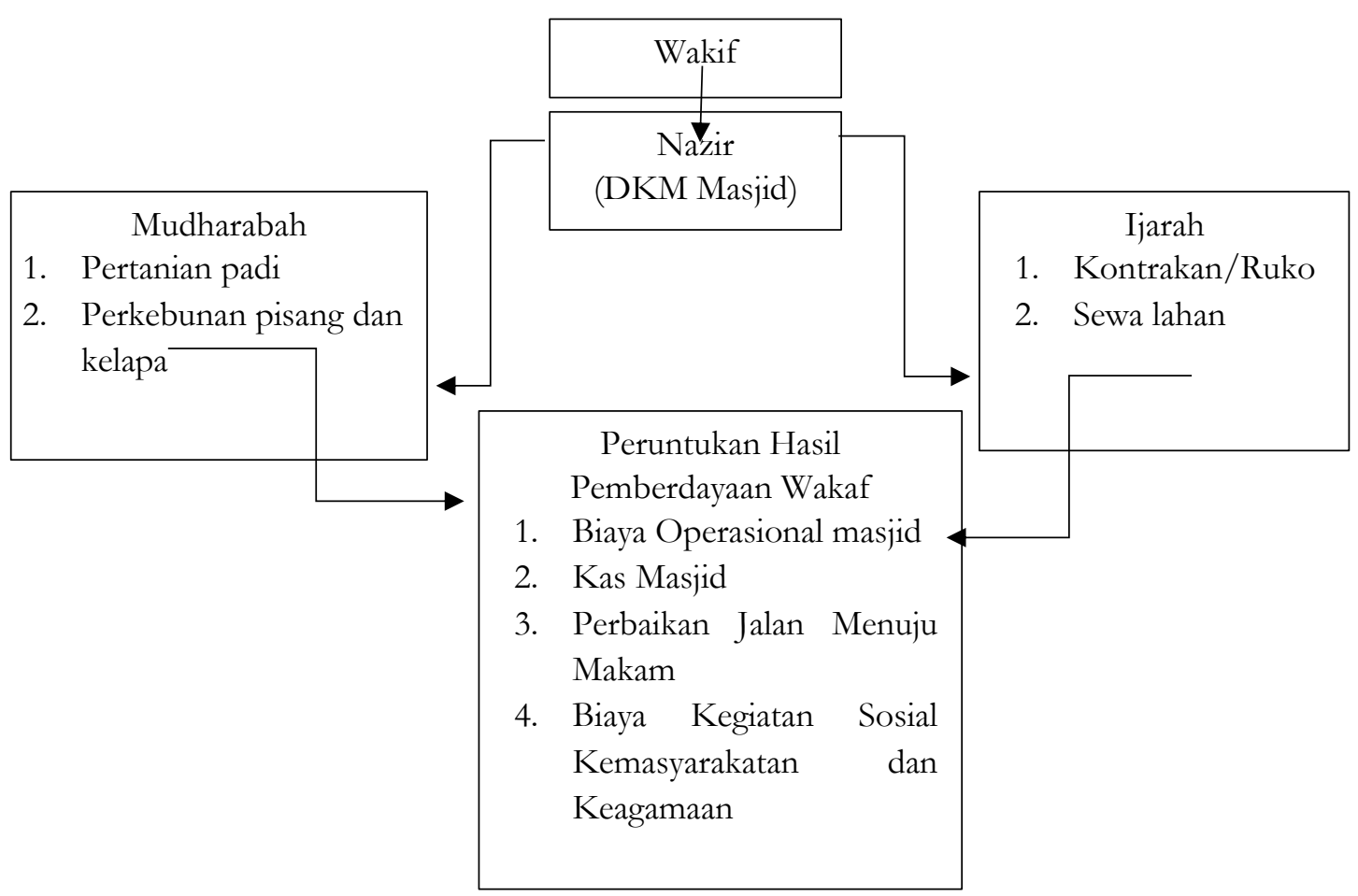

Bagan 1. Model Pemberdayaan Aset Wakaf dalam Pemberdayaan Ekonomi Masyarakat Desa

Berdasarkan bagan di atas, para nazir memberdayakan aset wakaf yang dikelolanya dengan skim mudharabah dan ijarah, mudharabah dilakukan dengan cara menyerahkan lahan sawah kepada penggarap untuk ditanami padi, setelah panen, hasil dibagi antara mudharib (pengelola) dengan nazir, sedangkan untuk lahan perkebunan pengelola menggunakannya untuk budidaya pisang dan kelapa, hasilnya juga dibagi dua antara pengelola dan nazir. Sedangkan yang Kedua skim ijarah, skim ijarah dilakukan dengan cara mengontrakan rumah kontrakan atau ruko yang dibangun di atas lahan wakaf pada penyewa, penghasilan pertahunnya mencapai kisahan sepuluh sampai limabelas juta, di samping itu, nazir juga menyewakan sawah kepada para petani dengan biaya sewa yang terjangkau. Seluruh hasil yang diperolah dari dua skim tersebut diperuntukan untuk simpanan kas masjid, biaya operasional masjid, perbaikan jalan menukuju makam dan biaya kegiatan sosial keagamaan dan kemasyarakatan. 


\section{Kesimpulan}

Berdasarkan hasil penelitian dan pembahasan di atas, maka dapat ditarik kesimpulan sebagai berikut. Pertama, Para wakif mewakafkan hartanya kepada nazir atas dasar spirit keagamaan dan pengharapan akan pahala jariah yang terus mengalir untuk wakif. Pengelola aset wakaf di tingkat desa provinsi Banten sebagian besar adalah Dewan Kemakmuran Masjid desa setempat, bukan nazir profesional yang telah dibentuk Badan Wakaf Indonesia. Sebagian besar lahan wakaf yang dikelola DKM belum memiliki sertifikasi wakaf. Pelaporan harta aset wakaf dilakukan dengan beberapa cara, di antaranya melalui pengumuman yang disampaikan sebelum pelaksanaan shalat berlangsung. Kedua, model pengelolaan aset wakaf dalam rangka pemberdayaan ekonomi masyarakat desa dilakukan dengan dua skim: mudharabah dan ijarah. Skim mudharabah dilakukan dengan mekanisme nazir menyerahterimakan aset wakaf berupa lahan pertanian dan perkebunan untuk dikelola oleh mudharib, setelah panin, hasil dibagi dua antara nazir dan pengelola. Skim ijarah dilakukan dengan cara mengontrakan rumah kontrakan atau ruko yang dibangun di atas lahan wakaf pada penyewa, penghasilan pertahunnya mencapai kisahan sepuluh sampai limabelas juta. Di samping itu, nazir juga menyewakan sawah kepada para petani dengan biaya sewa yang terjangkau. Seluruh hasil yang diperolah dari dua skim tersebut diperuntukan untuk simpanan kas masjid, biaya operasional masjid dan biaya kegiatan sosial keagamaan dan kemasyarakatan.

\section{Referensi}

Abdullah, A. R. (2013). Manajemen Wakaf Produktif: Studi Pendayagunaan Donasi Wakaf Bagi Pemberdayaan Ekonomi Umat Pada Dompet Dhuafa Republika.

bantenprov.go.id. (n.d.). Retrieved November 23, 2020, from https://dpmptsp.bantenprov.go.id

Bungin, H. M. B. (2013). Metodologi Penelitian Sosiale Ekonomi (1st ed.). Kencana Prenada Media Group.

Emzir. (2012). Metodologi Penelitian Kualitatif, Analisis Data (3rd ed.). Rajawali Pers.

Fauzia, D. A., Nani Almuin, M. ., Rohayati, T., \& Garadian, E. A. (2018). Fenomena Wakaf di Indonesia : Tantangan Menuju Wakaf Produktif(1st ed.). Badan Wakaf Indonesia.

Handayani, D. (2011). Pengelolaan Wakaf uang di Indonesia. Dinas Pendidikan Provinsi Banten.

Kurniawan, M. (2013). Wakaf Produktif Dan Pemberdayaan Ekonomi Umat. ASAS, 5, 43. http://ejournal.iainradenintan.ac.id/index.php/asas/article/view/157

Megawati, D. (2014). Pengelolaan Dan Pengembangan Wakaf Produktif Di Kota Pekanbaru. Hukum Islam, XIV(1), 104-124.

Mubarok, J. (2008). Wakaf Produktif. Simbiosa Rekatama Media.

Najib, M. A. (2017). Penguatan Prinsip Syariah Pada Produk Bank Syariah. Jurnal Jurisprudence, 7(1), 15-28. https://doi.org/10.23917/jurisprudence.v7i1.4351

Nazir, M., \& Sikumbang, R. F. (2014). Metode Penelitian. Ghalia Indonesia.

Qahaf, M. (2008). Manajemen WakafProduktif. PT. Khalifa.

Qohaf, M. (2006). Al-Waqfu al Islami, Tathomnurubu, Idratubu, Tanmiatuhu (1st ed.). Dar al-Fikri.

Salus, A. (2002). Mausu'ah al-qodhoya al-Fiqhiyah al-Mu'asiroh wa Al-Iqtishod Al Islami. Dar alQur'an.

Suharto, E. (2014). Membangun Masyarakat, Memberdayakan Rakyat; Kajian Strategis Pembangunan Kesejabteraan Sosial dan Pekerjaan Sosial.

Suryani, \& Isra, Y. (2016). Wakaf Produktif (Cash Waqf) Dalam Perspektif Hukum Islam Dan Maqasid Al-Shari'ah. Jurnal Penelitian Sosial Keagamaan, 24(1), 17-36. 